\title{
Charity and philanthropy
}

\section{Anne O'Brien}

The importance of charity and philanthropy in the lives of Sydney people has changed considerably since colonisation. In the nineteenth century, charity was the main institutional assistance protecting poor people from starvation and homelessness. After the introduction of benefits and pensions in the early and mid-twentieth century it remained important but less acutely so. In the closing decades of the twentieth century, as the government came to outsource many of the functions that had previously been assigned to the state, it regained some of the influence it had enjoyed in the nineteenth century.

These changes have been accompanied by shifts in the ways in which the terms charity and philanthropy have been used. For most of the nineteenth century, they were used largely interchangeably. Towards the end of the nineteenth century, philanthropy also became associated with the giving of large gifts or bequests, not only to assist the ill and needy but for the educational and cultural benefit of the community. Given this change, charity was used to describe institutional assistance to the needy for most of the twentieth century. In the early twenty-first century, the meanings of philanthropy shifted slightly again, as it came to be seen as a partner with business and government in strengthening 'social enterprise' or 'social entrepreneurship'.

Political understandings of the terms have also changed. In the late eighteenth and early nineteenth century, charity and philanthropy included impulses towards social reform but these had largely disappeared by the early twentieth century. However, the foundation in 1956 of the Australian Council of Social Service as an advocacy and lobby group was symptomatic of the reemergence of a social reform agenda for charity, now positioned within the broader sphere of community welfare.

Historians of Sydney philanthropy have shared the shifting assumptions of international studies: those published in the 1970s and 1980s, influenced by 'the new left', emphasised the desire to control and reform; in the 1980s feminists wrote of philanthropy's capacity to hone women's skills and provide them with a something of a public life; historians of volunteering in the 1990s widened the scope by positioning philanthropy within a range of community organisations. ${ }^{1}$ However, the distinctiveness of philanthropy in Sydney was distilled by the pioneering histories of charity in Australia which emphasised its close relationship with the state. ${ }^{2}$ 


\section{Charity and government welfare}

In Sydney the government was the main provider of welfare for the convict settlement but widespread disillusion with the British poor law during the colony's formative years gave voluntarism a special appeal. ${ }^{3}$ As a result Sydney charities took a characteristically hybrid form: although run by committees of citizens, they remained heavily subsidised by government. Government also took direct responsibility for more 'problem' groups than it later did in Melbourne. ${ }^{4}$ The Benevolent Society of New South Wales, founded in 1813 to provide 'outdoor relief' or rations, remained the dominant charity throughout the nineteenth century but the government paid for the building of the Asylum in 1821 and in 1862 assumed full responsibility for housing the poor who were aged and infirm. ${ }^{5}$ Similarly, while the wives of the colonial elite were instrumental in founding the first orphan schools, these were financed from Imperial revenue.

\section{The 'deserving' poor}

While philanthropy generally consolidated rather than challenged class boundaries, its institutions were shaped by shifting political and religious ideas. In the years immediately following its foundation, the Benevolent Society attributed poverty to Providence rather than personal fault and called for compassion for sufferers. By the later 1820s, in a context of increasing harshness within the convict system and the ascendancy of a more rigorous view of poor relief in England, an evangelical outlook that associated poverty with vice became dominant. ${ }^{6}$

In the 1830s, new charities created and maintained categories of deservingness. Reflecting the increasing numbers of free immigrants in the population, the Sydney Dorcas Society assisted married pregnant women during their confinements and the Sydney Strangers' Friend Society visited 'sick and distressed persons' in their homes. ${ }^{7}$ Retaining the more compassionate and providential view of poverty, their assistance at home of people considered deserving simultaneously preserved their recipients from having to publicly identify as impoverished and indirectly stigmatised those relying on the Benevolent Society. A similar desire to preserve the middle class from the disgrace of poverty underpinned the Home Visiting and Relief Society, which from 1863 to 1902 offered help to distressed members of 'the Educated Classes' who had seen 'better days. ${ }^{8}$ All charities were limited by fears that their recipients might become 'pauperised' or dependent on assistance, by the concern that assistance might be provided to the 'undeserving' and by a preference for selectivity that expunged the idea of a right to assistance.

\section{Rescuing children}

The work of the child rescue movement - an outgrowth of evangelical philanthropy - was also shared in Sydney between government and philanthropists. The government supported the widely held belief that the only hope for the colony rested with the 'rising generation' by establishing the 
Female Orphan School in 1801 and the Male Orphan School in 1818. Their later incarnations as Protestant and Catholic Orphan Schools in the 1830s reflected the growing strength of sectarianism. ${ }^{9}$ Fears of an urban underclass, manifest in select committees into intemperance and into the condition of the working classes in the 1850s, led to the foundation of industrial schools for boys on board the ships Vernon (1867) and Sobroan (1892), and for girls at Newcastle (1867) and later Parramatta (1887). The Female School of Industry (1826) and the Asylum for Destitute Children (1852) were both public charities run by committees of citizens. ${ }^{10}$

All these institutions shared the aspiration to cultivate industrious habits in their charges while keeping them within their own rank in society. So, too, did the 'progressive' movement to board children with respectable working class families. Born in the late 1870s of female philanthropic initiative - in particular that of Marian Jefferis - this idea was rapidly taken up by the government. ${ }^{11}$ Extolling the virtue of family ideology, it offered no assistance to the families from which the children came but effectively supplied intact families with cheap domestic, farm and other labour.

The introduction of boarding out signalled the closure of the government-funded Orphan Schools in 1886 but large institutions for children were founded by all the major Christian denominations in the later nineteenth and early twentieth centuries. The fact that the majority of these were Catholic reflects the Catholic preference for educating their members in Catholic teaching and the availability of women religious to work in the homes. ${ }^{12}$

Eschewing child removal, Ragged Schools were founded to educate children within their immediate environments. From the 1860s, Ragged Schools taught children literacy and numeracy in inner-city localities - Sussex Street, Globe Street, Harrington Street - and the inner suburbs of Glebe, Waterloo and Woolloomooloo. ${ }^{13}$

\section{Aboriginal charities}

In the early nineteenth century, Aboriginal people were seen as suitable subjects of philanthropy, as witnessed by William Shelley's idea for a Native Institution at Parramatta in 1814 and other schemes mooted around this time by Robert Cartwright and Richard Sadlier. ${ }^{14}$ However, missionary initiatives for Aborigines petered out in New South Wales from the 1840s to the late 1870s and charity came to be seen as the preserve of poor white people. In the work of George Ardill, there was some crossover between charities for Indigenous and non-Indigenous people. Founder of the Sydney Rescue Work Society (1890), which was dedicated to the 'rescue' of white women, he was also the most energetic member of the New South Wales Aborigines Protection Board between 1907 and 1916. His notions of 'rescue' are apparent in the workings of the Board and in the fact that Aboriginal children were sometimes sent to homes largely intended for white children. ${ }^{15}$ 


\section{Philanthropy and gender}

Nineteenth-century philanthropy enabled women and men to fulfil the expectations of a new gender order in distinct ways. For men of the middle class, it provided the opportunity to demonstrate respectability in a developing market economy that demanded a reputation for honourable business practice. ${ }^{16}$ Women's relationship with philanthropy was perhaps more complex. While philanthropy allowed women to exercise the compassion that had long been assumed natural to them, it also became a way in which they could reinforce the authority of a new model of useful and serious domestic femininity, which came to replace an older one associated with frivolity, decadence and decoration. While men comprised the committees of most public charities, from the early nineteenth century governors' wives - particularly Anna King, Elizabeth Macquarie and Eliza Darling - took active roles in various institutions. ${ }^{17}$ Over the course of the nineteenth century, while some women became benefactors and visitors of prisons and hospitals, most women in organised charity worked in auxiliaries, though these sometimes came to exercise power beyond their prescribed status. Between 1870 and 1900 there was an 'explosion' of charities run by women, in part because of the development of the belief that women could best assist other women, in part because increasing prosperity gave more women of the relevant age cohort the necessary leisure. ${ }^{18}$

Described as 'the taproot of female emancipation' in the nineteenth-century British world, philanthropy enabled women to extend their role beyond the domestic sphere. ${ }^{19}$ This possibility was exemplified most vividly in Sydney by Caroline Chisholm who, in 1841, founded a home for immigrant women and travelled with them to rural areas. By addressing public meetings on the issue of land reform, she not only transgressed the boundaries of women's sphere, she emphasised philanthropy's potential for social reform. ${ }^{20}$ The paradox she encapsulated espousing women's role in the family while moving beyond its confines - became more apparent as more women embraced philanthropy later in the century. A small number of women, including Rose Scott, founding secretary of the Womanhood Suffrage League of New South Wales, were predisposed to feminism because of the direct knowledge that philanthropy gave them of poor women's extreme vulnerability. ${ }^{21}$

\section{Poor women}

Women have also been the subjects of philanthropy to a greater extent than men, in part because their marginalisation in the labour market and their role within the family has made them more vulnerable to poverty - women have been estimated as comprising three-quarters of the poor across two centuries. ${ }^{22}$ Their perceived potential to either corrupt or purify has also made them vulnerable to philanthropy's desire for moral reform. It is no coincidence that the Female Orphan School targeted girls 17 years before a similar institution was opened for boys. Establishing a pattern followed by institutions for women through the rest of the century, it aimed to protect girls 
from exploitation, control their sexuality and transform them into virtuous women. ${ }^{23}$ By 1848 when the House of the Good Shepherd and the Sydney Female Refuge were founded in sectarian competition for 'fallen' Catholic and Protestant women respectively, women's apparent moral vulnerability and need for control and reform was firmly embedded. ${ }^{24}$ Between 1880 and 1920 the number of institutions for unmarried mothers and prostitutes expanded significantly as the major denominations and the committees of the Ashfield Infants Home and the Sydney Female Mission Homes were joined by the Salvation Army and the Sydney Rescue Work Society. ${ }^{25}$

\section{Charity and religion}

Most nineteenth-century public charities were imbued with a Protestant ethos and run by committees of Protestants, though the Catholic priest John McEncroe, described by his biographer as 'remarkable for his moderation', served on the committees of several public charities including the Benevolent Society of New South Wales. ${ }^{26}$ In addition to charities established to give aid, the Protestant city mission movement became an adjunct of philanthropy. Primarily intended to take the Gospel to the people of the inner city, its missionaries provided material assistance when they found themselves faced with acute suffering. Their visitation of the 'slums' was seen as enabling them to achieve more successfully than other charities the sort of personal moral reform that lay at the heart of the nineteenth-century philanthropic exchange.

The first city missionary, Nathaniel Pidgeon, evangelised in Sydney from 1841, his work formalised by the foundation of the interdenominational Sydney City Mission in $1862 .{ }^{27}$ In the later nineteenth century a number of Protestant denominations founded their own city missions: the Salvation Army commenced operations in Sydney in 1880; the Central Methodist Mission was opened in 1884; the Congregational Church ran the Sussex Street Mission from 1896 and the Presbyterian Church employed Eva Holland in a Settlement at Woolloomooloo from 1909. All these missions declared that their assistance was given regardless of creed.

Catholic assistance to the poor in the nineteenth century was associated with the figure of the priest. From John Joseph Therry's convict-era ministry of 'sickbed, suffering, death and burial' to the immunity from larrikin attack of the French Marist priests in The Rocks in the late nineteenthcentury, Catholic historiography has represented embattled priests as the friends of the poor. ${ }^{28}$ The ministry of the first religious sisters also encompassed visitation of the poor in their own homes, though decades of work in schools, orphanages and homes for unmarried mothers has all but obliterated this early work from popular memory. ${ }^{29}$ Catholic 'outdoor relief' was formalised in 1881, when engineer and sea-captain Charles O’Neill established a branch of the French charity, the St Vincent de Paul Society, in The Rocks. Its membership was restricted to men until 1963, but it became one of the largest continuing organisations of the laity in Australia. ${ }^{30}$ 


\section{New charities}

The dominance of the Benevolent Society in Sydney meant that the influence of the Charity Organisation Society, a British organisation that sought to streamline charities and avoid the overlapping of assistance, did not take off in Sydney as it did in Melbourne in the 1880s.

However, towards the end of the century, a number of smaller societies were established in the suburbs and country towns, adding their measure to the older Hawkesbury Benevolent Society (1819) and the Parramatta Benevolent Society (1838). Societies were founded at Balmain and Leichhardt during the 1880s (as well as in a number of country areas) and, in response to the depression, a considerable number of suburban societies were established during the early 1890s: at Ashfield, Kogarah, North Sydney, Paddington, Petersham and Marrickville. The early 1890s also saw the foundation of charities for ethnic groups: the French Benevolent Society, Kaiser Wilhelm Spende and the Highland Society of New South Wales. ${ }^{31}$

The foundation of these societies may well have marked the highpoint of charity but demonstrating its inability to cope with widespread distress - also signalled its decline. Philanthropy was challenged by the political philosophy of new liberalism, which envisaged an enhanced role for the state in mitigating the worst effects of capitalism. Its most significant manifestation was the introduction of an old age pension in New South Wales in 1901, though the boarding-out allowance paid to 'deserving' deserted wives and widows from 1896 was also important in providing a cash payment to struggling mothers rather than removing their children. ${ }^{32}$ However, government benefits and pensions did not spell the end of philanthropy. Suburban benevolent societies remained active in the 1910s and 1920s, city missions continued to offer assistance and in addition to the City Night Refuge and Soup Kitchen (1868), new shelters for homeless men were opened by the Central Methodist Mission in 1908 and the Salvation Army in 1912.

New charities were founded in the interwar years. For many groups - the aged and sick, large families and Indigenous people - these years may well have been 'one long depression'. It is significant that one of Sydney's most important charities, the Smith Family, was founded in 1922, well before the Wall Street crash. ${ }^{33}$ However, in the Depression, charities were stretched to the limit. Important conduits for government assistance, they received more funding for outdoor relief and were subject to a greater degree of coordination. ${ }^{34}$ The 1930 s saw new charities founded and old ones extended. Matthew Talbot Hostel was founded by the St Vincent de Paul Society in 1938. In 1933 Reverend RBS Hammond extended his Hammond Hotels, which had been providing accommodation for unemployed men since 1908, and opened Hammondville, a housing estate at Liverpool. ${ }^{35}$ In the years after World War II, the city missions began to offer homes for the aged, as did new church organisations such as the Baptist Community Services (1944). Homes for children and unmarried mothers remained in use until the 1970s. 


\section{Informal charity and self-help}

Autobiographies and case reports show that the informal provision of charity among and between people within local neighbourhoods was not uncommon: tradesmen waived debts, landladies did not always insist on rent and neighbours minded children and shared food. ${ }^{36}$ Mutual aid was formalised through friendly societies, the first of which was established in the 1830s. ${ }^{37}$ Although these were embraced in large numbers - by 1880 there were 35,000 Friendly Society members in New South Wales - they offered only short-term assistance in cases of temporary illness or funeral costs. ${ }^{38}$

The twentieth century saw the formation of groups with a self-help orientation, such as the Legacy Club, formed by ex-veterans in 1923 to assist the widows and children of those who died in war, and the Civilian Widows Association, founded in $1949 .{ }^{39}$ While the Jewish community had cared for its members since the Hebrew Philanthropic Society was formed in 1833, from the mid-twentieth century it was active in providing assistance to Jewish refugees. ${ }^{40}$ Following the introduction of large-scale non-British immigration in the late 1940s, other ethnic groups established charitable and community support organisations, such as the Australian German Welfare Society. ${ }^{41}$ These were assisted by the policy of multiculturalism and respect for ethnic difference which strengthened the idea of community self help. ${ }^{42}$

\section{Organised charities}

In 1936, charities were among the many community organisations that joined to form the New South Wales Council of Social Service. This began as an attempt to coordinate the ad hoc and disjointed responses which met the suffering of the Depression. However, it became - alongside the Australian Council of Social Service (ACOSS) founded in 1956 - a significant voice seeking improved funding and services for disadvantaged groups. ${ }^{43}$ For over 30 years these peak bodies worked with the architects of the social security state, which expanded in both the 1940s and the 1970s. The advent of a neo-liberal economic agenda in the 1980s, and the significant cutbacks to welfare spending under the federal Coalition government between 1996 and 2007, saw ACOSS and some of its member organisations such as the Salvation Army and the St Vincent de Paul Society having to defend the very idea of the welfare safety net. ${ }^{44}$ At the same time, these charities were prominent among the groups to whom the government outsourced the distribution of employment benefits under its Jobs Network scheme in 1998. This situation gave rise to considerable tension, especially when welfare 'providers' were asked to implement policies they saw as unjust, and it forced a new political commitment from long-established charities. ${ }^{45}$ In 2002, the St Vincent de Paul Society argued that the government's policies withdrawing benefits from people who breached job-searching conditions were 'a wholesale scapegoating and punishment of the vulnerable. ${ }^{46}$ 


\section{Business philanthropy}

The tradition of business philanthropy in Sydney is considerably less developed than in Melbourne but individuals have made notable contributions: Sir James Burns of Burns Philp endowed Burnside Children's Homes; mining magnate and pastoralist Sir Thomas Buckland endowed Buckland Convalescent Home at Springwood; tobacco manufacturer Sir Hugh Dixson and his wife Emma gave large amounts to many charities including the Homes for Incurables, Ryde; merchant and manufacturer Ebenezer Vickery gave the Lyceum Theatre to the Central Methodist Mission; and musician and merchant WH Paling endowed the Home for Convalescents at Camden. ${ }^{47}$ While large donations of this sort were not usually accompanied by the desire for social reform, Sir Frederick Stewart's endowment of the Lottie Stewart Hospital - in memory of his wife - was one aspect of a political career that sought 'industrial reform, shorter working hours and comprehensive social betterment programs. ${ }^{48}$

Business philanthropy in Australia as a whole is less developed than in the United States and the Howard government's retraction of public welfare was accompanied by a rhetoric encouraging the business community to be more socially responsible and to show leadership in philanthropy. ${ }^{49}$ The new language of ‘social entrepreneurship' and ‘social enterprise' has survived the Howard government. Developing around the nexus between business and philanthropy, it is nurtured in ventures such as the Centre for Social Impact at the University of New South Wales.

The historical similarities between the socio-economic conditions at the turn of the nineteenth and the turn of the twenty-first centuries are striking: in both eras philanthropy gained greater status as the market economy grew and there was a growing tendency to blame the poor for their difficult circumstances.

Anne O'Brien is Associate Professor in the School of History and Philosophy at the University of New South Wales in Sydney

\section{Endnotes}

${ }^{1}$ Elizabeth Windschuttle, 'Feeding the poor and sapping their strength' in Elizabeth Windschuttle (ed), Women, Class and History: Feminist perspectives on Australia 1788-1978, Fontana, Melbourne, 1980; Richard Kennedy (ed), Australian Welfare History: Critical Essays, Macmillan, Melbourne, 1982; Judith Godden, 'Philanthropy and the women's sphere', PhD thesis, Macquarie University, 1983; Melanie Oppenheimer, “"We all did voluntary work of some kind”: voluntary work and labour history', Labour History, no 81, Nov 2001

${ }^{2}$ Dora Peyser, 'A study of the history of welfare work in Sydney from 1788 till about 1900', Journal of the Royal Australian Historical Society, vol XXV, part 1, 1939; Brian Dickey, 'Charity in New South Wales: a study in public, private and state provisions for the poor', $\mathrm{PhD}$ thesis, Australian National University, 1966

${ }^{3}$ John Hirst, 'Keeping colonial history colonial: the Hartz Thesis revisited', Historical Studies, vol 21 no 22, April 1984, pp 85-96 


\section{Endnotes}

${ }^{4}$ Shurlee Swain, 'Philanthropy', in Andrew Brown-May and Shurlee Swain (eds) The Encyclopaedia of Melbourne, Cambridge University Press, Cambridge, 2005, pp 541

${ }^{5}$ Brian Dickey, No Charity There, Allen \& Unwin, Sydney, 1984, p 34

${ }^{6}$ Anne O’Brien, “'Kitchen Fragments and Garden Stuff”: Poor Law Discourse and Indigenous People in Early Colonial New South Wales', Australian Historical Studies, vol 39 no 2, 2008

${ }^{7}$ Sydney Dorcas Society, Report, 1840, p 6; Sydney Strangers' Friend Society, Report, 1842, pp 5-9

${ }^{8}$ Home Visiting and Relief Society, First Annual Report, 1863, p 1

${ }^{9}$ After the Catholic children were removed to an orphanage at Waverley in 1836, the terms Catholic Orphan School and Protestant Orphan School were frequently used, even though the Protestant Orphan School was not formally established until 1849. John Ramsland, Children of the Backlanes, University of New South Wales Press, Sydney, 1986, pp 54-5

${ }^{10}$ John Ramsland, Children of the Backlanes, University of New South Wales Press, Sydney, 1986

${ }^{11}$ John Ramsland, Children of the Backlanes, University of New South Wales Press, Sydney, 1986, p 1834

${ }^{12}$ Anne O’Brien, Poverty's Prison: The poor in New South Wales 1880-1918, Melbourne University Press, Melbourne, 1988, pp 216-7

${ }^{13}$ John Ramsland, Children of the Backlanes, University of New South Wales Press, Sydney, 1986, pp 9099

${ }^{14}$ Anne O’Brien, “'Kitchen Fragments and Garden Stuff”: Poor Law Discourse and Indigenous People in Early Colonial New South Wales', Australian Historical Studies, vol 39 no 2, 2008

${ }^{15}$ Naomi Parry, 'Such a Longing: black and white children in welfare in New South Wales and Tasmania, 1880-1940', PhD thesis, University of New South Wales, 2007

${ }^{16}$ Catherine Hall, White, Male and Middle Class: Explorations in feminism and history, Routledge, New York, 1992, pp 75-93

${ }^{17}$ Elizabeth Windschuttle, 'Feeding the poor and sapping their strength', in Elizabeth Windschuttle (ed), Women, Class and History: Feminist perspectives on Australia 1788-1978, Fontana, Melbourne, 1980

${ }^{18}$ Judith Godden, 'British Models and Colonial Experience: Women’s Philanthropy in Late Nineteenth Century Sydney’, Journal of Australian Studies 19, November 1986, p 48

${ }^{19}$ Frank Prockashka, 'Review: The Angel out of the House: Philanthropy and Gender in NineteenthCentury England, by Dorice Williams Elliot’, Victorian Studies, vol 46, no 1, Autumn, 2003

${ }^{20}$ Margaret Kiddle, Caroline Chisholm, Melbourne University Press, Melbourne, 1950

${ }^{21}$ Judith Allen, Rose Scott: Vision and revision in feminism, Oxford University Press, Melbourne, 1994, pp 81-7

${ }^{22}$ Patricia Harris, 'Penny-pinching activities: managing poverty under the eye of welfare', in Kay Saunders and Raymond Evans (eds), Gender Relations in Australia, Harcourt, Brace Jovanovich, Sydney, 1992, pp 287-301; Anne O’Brien, Poverty's Prison: The poor in New South Wales 1880-1918, Melbourne University Press, Melbourne, 1988, pp 89-100

${ }^{23}$ John Ramsland, Children of the Backlanes, University of New South Wales Press, Sydney, 1986, pp 320 


\section{Endnotes}

${ }^{24}$ Judith Godden, 'Sectarianism and purity within the women's sphere: Sydney refuges for ex-prostitutes in the late nineteenth century', Journal of Religious History, vol 14, no 3, June 1987, pp 291-306

${ }^{25}$ Anne O’Brien, Poverty's Prison: The poor in New South Wales 1880-1918, Melbourne University Press, Melbourne, 1988, pp 206-7

${ }^{26}$ PK Phillips, 'McEncroe, John (1794-1868)', Australian Dictionary of Biography vol 2, Melbourne University Press, Melbourne, 1967, pp 165-166

${ }^{27}$ June Owen, The heart of the city: the first 125 years of the Sydney City Mission, Kangaroo Press, Sydney, 1987

${ }^{28}$ Patrick O'Farrell, The Catholic Church and Community, University of New South Wales Press, Sydney, 1985, p 23; Stephen Utick, Captain Charles, Engineer of Charity, Allen \& Unwin, Sydney, 2008, pp $163-4$

${ }^{29}$ Edmund Campion, Australian Catholics: The contribution of Catholics to the development of Australian Society, Viking, Melbourne, 1987, p 35

${ }^{30}$ Stephen Utick, Captain Charles, Engineer of Charity, Allen \& Unwin, Sydney, 2008

${ }^{31}$ Statistical Register of New South Wales, 1895, p 849

${ }^{32}$ Stephen Garton, 'Rights and Duties: Arguing charity and welfare 1880-1920', in M Wearing and R Bereen (eds), Welfare and Social Policy in Australia: the distribution of advantage, Harcourt Brace, Sydney, 1994

${ }^{33}$ Stephen Garton, Out of Luck, Sydney, Allen \& Unwin, 1990, ch 6

${ }^{34}$ F A Bland, 'Unemployment Relief in Australia', in Jill Roe (ed), Social Policy in Australia: Some perspectives 1901-1975, Cassell, Sydney, 1975

${ }^{35}$ Stephen Judd and Kenneth Cable, Sydney Anglicans, Anglican Information Office, Sydney, 2000, pp 202-3

${ }^{36}$ Anne O’Brien, Poverty's Prison: The poor in New South Wales 1880-1918, Melbourne University Press, Melbourne, 1988, pp 28-31

${ }^{37}$ David Green and Lawrence Cromwell, Mutual Aid or Welfare State: Australia's Friendly Societies, , Allen \& Unwin, Sydney, 1984

${ }^{38}$ Stephen Garton, Out of Luck, Allen \& Unwin, Sydney, 1990, p 57

${ }^{39}$ Stephen Garton, The Cost of War: Australians Return, Oxford University Press, Melbourne, 1996, p 203

${ }^{40}$ Suzanne D Rutland, Edge of the Diaspora: Two Centuries of Jewish Settlement in Australia, Brandl and Schlesinger, Sydney, 1997, pp 31-2, 251-6

${ }^{41}$ Australian German Welfare Society, Annual Report, 1970

${ }^{42}$ A Jakubowicz, 'Welfare Provision', in James Jupp (ed), The Australian People, Angus \& Robertson, Sydney, 1988, pp 965-5

${ }^{43}$ Susan Keen, A Brief History of NCOSS, NCOSS News, vol 32, no 7, August 2005; Philip Mendes, Australia's Welfare Wars: The players, the politics and the ideologies, University of New South Wales Press, Sydney, 2003, pp 121-2

${ }^{44}$ Philip Mendes, Australia's Welfare Wars: The players, the politics and the ideologies, University of New South Wales Press, Sydney, 2003, p 127 


\section{Endnotes}

${ }^{45}$ Philip Mendes, Australia's Welfare Wars: The players, the politics and the ideologies, University of New South Wales Press, Sydney, 2003, p 165

${ }^{46}$ St Vincent de Paul Society media release 'Vinnies asks: why are the poor being treated like criminals?' 12 March 2002, https://www.vinnies.org.au, accessed 1 September 2008

${ }^{47}$ See entries in the Australian Dictionary of Biography

${ }^{48}$ CJ Lloyd, 'Stewart, Sir Frederick Harold (1884-1961)', Australian Dictionary of Biography, vol 12, Melbourne University Press, Melbourne, 1990, pp 87-89

${ }^{49}$ Philip Mendes, Australia's Welfare Wars: The players, the politics and the ideologies, University of New South Wales Press, Sydney, 2003, p 137 